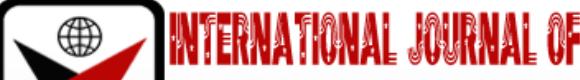

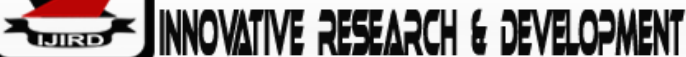

ISSN 2278 - 0211 (Online)

\section{Public Financial Management System and Public Expenditure on ICT Infrastructural Development in Nigeria}

Adedokun Y.
Ph.D. Student, Department of Accounting,
Babcock University, Ilishan-Remo, Ogun State, Nigeria
Akintoye I. R.
Professor, Department of Accounting,
Babcock University, Ilishan-Remo, Ogun State, Nigeria
Owolabi, S. A.
Professor, Department of Accounting,
Babcock University, Ilishan-Remo, Ogun State, Nigeria

\begin{abstract}
:
This study investigated the effect of public financial management system on public expenditure on ICT infrastructural development in Nigeria. The study employed survey research design. The population of the study comprised 584 employees drawn from the Federal Ministry of Communications and Digital Economy. A sample of 68 employees was selected using purposive sampling technique based on the knowledge and skills of the employees. The study through multiple regression analysis found that public financial management system had positive and significant effect on public expenditure on ICT infrastructural development in Nigeria (Adj. $\left.R^{2}=0.418, F(5,57)=9.897, p<0.05\right)$. The study concluded that public expenditure on ICT infrastructural development is influenced by public financial management system in Nigeria. It was recommended that the Federal Government of Nigeria should further enhance sound public financial management system in the Ministry of Communications and Digital Economy in order to improve ICT infrastructural development and ensure the control and monitoring of public resources meant for ICT infrastructural development by using public financial management system tools.
\end{abstract}

Keywords: Public expenditure, public financial management system and ICT infrastructure

\section{Introduction}

Nigeria at independence and other Africa nations focused on enhancing economic and social progress and the government main strategy was development planning used in setting their visions, goals, missions and effectively actualize their economic and social objectives (Olokesusi, 2011). The Nigeria government in 1960 from independence was saddled with the responsibilities of planning and directing economic growth and development of Nigeria; the rate of illiteracy was reduced by expanding education progressively to produce competent and relevant workforce skills for development, roads and communication network infrastructure were constructed above those inherited from the colonial master, there were construction of hydroelectric dams to generate and distribute electricity, automobile assembly plants and secondary industries were established to provide employment opportunities for citizens (UNDP, 2002). The population increase of Nigeria has increased the need for infrastructural services which has also led to important policy problem (Lee \&Anas, 1992). Infrastructure enhances economic growth and development of a nation. The Nigerian economy could be enhanced when there are present of infrastructure (Nedozi, Obasanmi\&Ighata, 2017). But, Nigeria may find it difficult to sustain the population increase and the economic growth if infrastructural facilities are not improved (Adekalu, 2016). World Bank's Development Report (1994) asserts that one percent of increase in infrastructural facilities is connected with one percent of increase in the Gross Domestic Product. The continuous increase in population is also leading to strain and demands on the available infrastructure in the country and the problem needs to be addressed quickly (Nwachukwu, 2020).

Public Financial Management System (PFMS) is the basis of all public sector activities (Simson, Sharma \& Aziz, 2011). One of the main macroeconomic objectives of all countries is achieving efficient allocation of resources and business cycle stabilization (Ogujiuba\&Okafor, 2013). Public Financial Management cycle begins with policy design and ends with external audit (Lawson, 2015).Prakash and Cabezon (2008) asserts that PFM is an essential instrument for implementing economic policy, and it performs this activity by impacting the allocation and use of public resources through budgeting and overall fiscal policy. The several PFM processes are organized around the budget cycle, which enables public expenditure planning, execution and accounting; the budget cycle comprises of the budget formulation, budget execution, accounting and reporting and external oversight (Simson et. al., 2011). The management of resources at different levels are always represented by tangible goods and services either by individuals or entity (Sirmon, 
Hitt\&Ireland, 2007)).The expenditure incurred by the government and the quality of those expenditures have significant impacts on the management of public treasury, service delivery and lower poverty level (The World Bank, 2018).

The Sustainable Development Goal 9 (SDG 9) emphasized 'industry, innovation and infrastructure' which is a section of the 17 Sustainable Development Goals. The SDG 9 aimed at building resilient infrastructure, foster innovation and promote sustainable industrialization (HLFP, 2017). The main challenges in Nigeria are: improving internet access, inadequate transport, disparity of research and development investment and numbers of researchers (HLFP, 2017). Hence, the thrust of this study is to examine the effects of Public Financial Management System on ICT infrastructural development in Nigeria. The hypothesis is as follows:

- Ho: Public Financial Management System exerts no significant effect on public expenditure on ICT composite infrastructure in Nigeria.

\section{Review of Related Literature}

\subsection{ICT Infrastructure}

ICT is an acronym for Information and Communication Technology. The concept ICT could also be referred to as "technologies that provide access to information through telecommunications, it is similar to information technology (IT), but focuses primarily on communication technologies, this includes the internet, wireless networks, cell phones, and other communication medium" (TechTerms, 2020). Information Technology is as old as man, there have been various ways of communicating based on the available technology at that point in time, four major ages divided the information technology history, the pre-mechanical age when language and simple pictures drawings were carved on rocks, mechanical age when analog computers (slide rules) were used for dividing and multiplying, electromechanical age when telegraph, telephone, radio, and the first large-scale automatic computer were invented, and the electronic age that we are in now where digital computers are used for processing information and communication (Brady \&Elkner, 2017). The term Information Technology evolved in the 1970s, comprises mostly computer hardware and software application and consist of study, advance development, design, administration of computer foundation information system, accomplishment, often computer hardware and software application work together to defend, broadcast, renovate and develop other information; currently IT has broaden to encompass electronic communication field and the acronym ICT is now in use, computers are put to use in new ways daily, affordability is increasing, becoming more powerful tools for processing information and less cumbersome to use (National University of Singapore, 2008).

ICT covers all various aspects of life, giving human beings newer, quicker and better ways of interacting, networking, accessing, seeking help and learning from people (Brown, 2020). ICT is everywhere today, and it has unlimited economic significance, according to a forecast by the International Data Corporation (IDC) (2020) global ICT spending will rise to $\$ 4.3$ trillion in 2020 which is an increase of $3.6 \%$ above 2019 figure, public sector and commercial spending on software, hardware, and IT services, telecommunications services, and business services will account for almost 2.7trillion of 2020 total and consumer spending on ICT will make up the remainder; business organizations and public sector organizations are inventing innovative services and products to drive new ICT investment, many organization are now investing in mobility, artificial intelligence, cloud, robotics, and increasingly in edge and DevOps computing which will enhance economic sustainability. Information Communications Technology (ICT) infrastructure means "the information and communications technology infrastructure and systems (including software, hardware, firmware, networks and the company websites) that are or have been used in the business" (Law Insider, 2020). ICT infrastructure is capable of achieving sustainable social and economic development in the society (Oloruntoyin\&Adeyanju, 2013).

\subsection{Public Financial Management System}

Public Financial Management System is concerned with the management of government expenditures, public debts, taxation borrowing, and liquidity level in the economy, foreign reserves, foreign exchange system, public debts, and public finance auditing so as to achieve some specific objectives (Nwezeaku, 2010). It embraces a larger set of functions which begins with policy design and ends with external audit and evaluation. PFM is very essential to basic economic governance and important in ascertaining the accountability, legitimacy and performance of functional states; it deals with the effective funds administration, it's a basis for all government activities, and encompasses all components of budget cycle of a nation which includes: revenue mobilization, fund allocation to various activities and the accounting for expenditure and spent funds; ineffective PFMS hinder development and broadens corruption risk (Government of Canada, 2017).

A strong Public Financial Management System should consist of "a strong and well organized Ministry of Finance equipped with the necessary administrative capacity and supported by a legal framework that allows it to exercise its role; cost effective public internal financial control systems, incorporating financial management and control and internal audit, across the entire public administration; an independent and professional Supreme Audit Institution supported by a legal framework which allows for high-quality audits that impact on public sector functioning; public procurement (including public/private partnerships and concessions) is an integral part of an effective public administration and public financial management, as it is one of the key means by which public money is spent in order to provide public services, good public procurement requires: a regulatory framework that contains policies and procedures to guide the work of contracting authorities and helps ensure economy, efficiency, transparency, accountability and access to justice in public procurement; institutional structures, operational capacities and market conditions needed for the effective implementation of the 
regulatory framework; and sound and efficient public procurement operations which deliver value for money (SIGMAOECD, 2014).

\subsection{Theoretical Framework}

\subsubsection{System Theory}

System theory was propounded by David Easton in 1965. He posits that system theory emphasizes a set of model inter-relationships which involves mutual interactions, and a high degree of connections among the members of a system. The theory is hinged on the notion that elements within a group are inter-related to each other and likewise interact with one another based on specific known processes. The theory establishes mutual relationships between the elements in a system, therefore, "a holistic, organized unit of interdependent, transacting and mutually influencing parts (individuals or collectives and their sub-units) within an identifiable (socio-ecological) environment (Siporin, 1975). System theory is an interdisciplinary theory which encompasses every system in nature, in scientific domain and in society and also a framework used to investigate phenomena as a whole (Capra, 1997). Some researchers recognized system theory that organizations are made up of complex social systems and an attempt to separate the parts from the whole lead to reduction in the overall effectiveness of the organization (Schein, 1980).

The theory is used in this research work to show how the public financial management practices of budgeting, accounting and reporting system, internal control system, public procurement laws and external audit and oversight work as a system to make sure that public funds are utilized efficiently and effectively to provide services to the populace in a country. Public financial management system comprises of major sub-components referred to as planning and budgeting, collection of revenue, accounting, auditing, and governance (Broback\&Sjolander, 2002). The sub-components are viewed as a system of connected elements that development of one sub-component relies and conditioned on the other components state if the objectives of development are to be met by the government (Andersen \&Isaksen, 2013). The PFM sub-components (budgeting, accounting and reporting system, internal control system, public procurement laws and external audit and oversight) are very important and needs to be enhanced in achieving development objectives. Thus, the sub-components in this study were used to examine how PFMS can influence one another and also influence infrastructural development in Nigeria. The theory revealed the interactions and the relationships which exist between the government officials that manage public funds in order to understand government organization, functioning and outcomes.

\subsection{Empirical Review}

Prior studies on Effect of Public Financial Management System on Public Expenditure on ICT Composite Infrastructural Development are limited (Bariu, 2020; Bahrini, \&Qaffas, 2019; Pradhan, Mallik, \&Bagchi, 2018; Bankole, \&Mimbi, 2017). Many of the studies reviewed the effect of ICT on Public Financial Management System, which is the reverse. This current study will provide literature on the subject matter and becomes the basis for future studies, and will empirically analyze the effect of Public Financial Management System on Public Expenditure on ICT Composite infrastructure.

ICT infrastructure causes a boost in the per capita GDP; to improve economic growth of a nation, ICT infrastructure need to be upgraded and expanded giving specific audience to broadband adoption and internet users (Pradhan \&Bagchi, 2018). The developing nations did view the industry growth of domestic ICT infrastructure as a means of achieving effective related development goals, which includes: attracting foreign direct investments, satisfying the demands for ICTs in the local market, provide basis for transfer of technologies, and the generation of continuous growth in the marketing and financial services (upstream and downstream) (Tolica, Sevrani\&Gorica, 2015). Africans are advised to invest in ambitious programs like integrated ICT infrastructure and satellites (Gabreab, 2002), The Infrastructure Consortium for Africa (ICA) also reported that "ICTs infrastructure are transformational drivers of both economic and social progress; they have the potential to make Africa a better place, and to greatly improve the lives of Africa's people; the growth of mobile telephony across Africa has been a notable success story, leading to improvement in the lives of Africa's people, both urban and rural; however, $75 \%$ of the population of Africa are still offline, denied access to the wealth and breadth of knowledge, information and services that the internet can bring; access to the internet can play an important role, advancing skills and capabilities, and increasing awareness, but only $15 \%$ of households in Africa have internet access".

Increase in the usage of ICT infrastructure enhances productivity and innovations, technical efficiency and scarce resources allocation (Bankole, Osei-Bryson \& Brown, 2011). Ngwenyama, Andoh-Baidoo, and Morawczynski (2006) asserted that there exist a positive relationship between ICT investments and education and health sectors and performance on the human development index in some of the Sub-Saharan Africa countries. This study will help to guide the Nigeria government on how to monitor spending on ICT infrastructure in order to produce efficient results.

\section{Methodology}

Survey research design was used for this study, focused on the Federal Ministry of Communications and Digital Economy and their operational activities in the account and finance department, public procurement department and internal audit department. These departments are in charge of disbursing public expenditure on ICT infrastructure. The population of the study comprised 584 employees drawn from the Federal Ministry of Communications and Digital Economy. A sample of 68 employees was selected using purposive sampling technique based on the knowledge and skills of the employees. Multiple Regression statistics were used to analyze the data. 


\section{Data Analysis, Interpretation and Discussion of Findings}

- Hypothesis:Public Financial Management System exerts no significant effect on public expenditure on ICT composite infrastructure in Nigeria.

\begin{tabular}{|c|c|c|c|c|}
\hline \multirow{2}{*}{ Variable } & \multicolumn{5}{|c|}{ Model 3 } \\
\cline { 2 - 5 } & Coefficient & Std Error & t-Stat. & Prob. \\
\hline C & 0.356 & 0.588 & 0.606 & 0.547 \\
\hline BGP & 0.250 & 0.087 & 2.873 & $0.006^{* *}$ \\
\hline ARS & 0.066 & 0.088 & 0.751 & 0.455 \\
\hline ICS & 0.143 & 0.098 & 1.457 & 0.151 \\
\hline PPS & 0.218 & 0.084 & 2.592 & $0.012^{*}$ \\
\hline EAO & 0.263 & 0.084 & 3.137 & $0.003^{*}$ \\
\hline R $^{2}$ & \multicolumn{5}{|c|}{0.465} \\
\hline Adjusted R & 0.418 & 0.18135 \\
\hline S.E of Reg & \multicolumn{5}{|c|}{$0.000^{*}$} \\
\hline F-Statistic & \multicolumn{5}{|c|}{62} \\
\hline Prob.(F-Stat) & \multicolumn{5}{|c|}{} \\
\hline Obs & \multicolumn{5}{|c|}{} \\
\hline
\end{tabular}

Table 1: Regression Estimate

Source: Researcher's Study, 2021

Model

$\mathrm{ICT}_{\mathrm{i}}=\alpha_{0}+\alpha_{1} \mathrm{BGP}_{\mathrm{i}}+\alpha_{2} \mathrm{ARS}_{\mathrm{i}}+\alpha_{3} \mathrm{ICS}_{\mathrm{i}}+\alpha_{4} \mathrm{PPS}_{\mathrm{i}}+\alpha_{5} \mathrm{EAO}_{\mathrm{i}}+\mu_{1 \mathrm{i}}$

$\mathrm{ICT}_{\mathrm{i}}=0.356+0.250 \mathrm{BGP}_{\mathrm{i}}+0.066 \mathrm{ARS}_{\mathrm{i}}+0.143 \mathrm{CS}_{\mathrm{i}}+0.218 \mathrm{PPS}_{\mathrm{i}}+0.263 \mathrm{EAO}_{\mathrm{i}}+\mu_{\mathrm{i}}$

\subsection{Interpretation}

The Hypothesis of this study aimed to determine if Public Financial Management System (budgeting, accounting and reporting system, internal control system, public procurement system, external audit and oversight function) exerts no significant effect on public expenditure on ICT composite infrastructure in Nigeria. To fulfil the hypothesis of the study, Public Financial Management System was used as independent variable while public expenditure on ICT composite infrastructure in Nigeria (ICT) was used as dependent variable. Observable in the result presented above, ALL the proxies employed for this study was examined and decisions were made using the p-values of the results. Considering the signs and magnitude of the estimated parameters, the values of all the proxies for the independent variable (budgeting (BGP), accounting and reporting system (ARS), internal control system (ICS), public procurement system (PPS), and external audit and oversight function (EAO))are positive. There exists a positive relationship between all the proxies of public financial management system and public expenditure on ICT composite infrastructure in Nigeria. This is represented by the signs of the coefficients $\alpha_{1}, \alpha_{2}, \alpha_{3}, \alpha_{4}$ and $\alpha_{5}$ i.e., $0.250 \mathrm{BGP}, 0.066 \mathrm{ARS}, 0.143 \mathrm{ICS}, 0.218 \mathrm{PPS}$, and $0.263 \mathrm{EAO}$ respectively.

This shows that $1 \%$ increase in BGP will lead to $25 \%$ increase in ICT, $1 \%$ increase in ARS will lead to $6.6 \%$ increase in ICT, $1 \%$ increase in ICS will lead to $14.3 \%$ increase in ICT, $1 \%$ increase in PPS will lead to $21.8 \%$ increase in ICT and 1\% increase in EAO will lead to $26.3 \%$ increase in ICT. The value of the constant implies that if the independent variables employed do not exist, ICT infrastructure in Nigeria (ICT) would still maintain a positive value of 0.356.

The adjusted $\mathrm{R}^{2}$ value of $41.8 \%$ for this model connotes the ability of the all the independent variables to collectively explain $41.8 \%$ variation in public expenditure on ICT infrastructure in Nigeria (ICT). The comparison of the $\mathrm{R}^{2}$ and adjusted $\mathrm{R}^{2}$ implies that there is good fit of the model.

The t-statistics reflects the individual significance of the variables in this model. It showed that only BGP, PPS and EAO had significant relationship with public expenditure on ICT infrastructure when isolated independently From the Table 4.31 result, public financial management system (budgeting (BGP), accounting and reporting system (ARS), internal control system (ICS), public procurement system (PPS), external audit and oversight function (EAO)) have significant combined effect on ICT infrastructure at 5\% level of significance. The F-statistics measures the overall performance of the public expenditure on transport infrastructure in the study. The F-statistics value for this model is 9.897. The significance of this model is ascertained using the p-values, the p-value $<0.05$. Considering this, this study shows that combined proxies of public financial management system that is, budgeting (BGP), accounting and reporting system (ARS), internal control system (ICS), public procurement system (PPS), external audit and oversight function (EAO)has a significant effect on public expenditure on ICT infrastructure in Nigeria (ICT).

At level of significance $0.05, F(5,57)=9.897$, while the p-valueis $0.000<0.05$. The study therefore failed to accept the null hypothesis which says that Public Financial Management System (budgeting, accounting and reporting system, internal control system, public procurement system, external audit and oversight function) exerts no significant effect on public expenditure on ICT composite infrastructure in Nigeria.

\section{Discussion of Findings}

The results of this study show that there is apositive relationship between budgeting, accounting and reporting system, internal control system, public procurement system, and external audit and oversight function with public expenditure on ICT infrastructure. Ngwenyama, Andoh-Baidoo, and Morawczynski (2006) asserted that there exist a 
positive relationship between ICT investments and education and health sectors and performance on the human development index in some of the Sub-Saharan Africa countries. ICT infrastructure causes a boost in the per capita GDP; to improve economic growth of a nation, ICT infrastructure need to be upgraded and expanded giving specific audience to broadband adoption and internet users (Pradhan and Bagchi, 2018).

This current study found that only budgeting, public procurement system and external audit and oversight function had significant relationship with public expenditure on ICT infrastructure when isolated independently but this study also shows that combined proxies of public financial management system i.e. budgeting, accounting and reporting system, internal control system, public procurement system, external audit and oversight functionhave significant positive effect on public expenditure on ICT infrastructure in Nigeria (ICT). Studies by (Bariu, 2020; Bahrini, \&Qaffas, 2019; Pradhan, Mallik, \&Bagchi, 2018; Bankole, \&Mimbi, 2017) contradict these findings because they are reverse, the researchers reviewed the effect of ICT on Public Financial Management System. The researcher found evidence of the significant impact of public financial management system on ICT composite infrastructure from this study.

\section{Conclusion and Recommendations}

The study concluded that public expenditure on ICT infrastructural development is influenced by public financial management system in Nigeria. It was recommended that the Federal Government of Nigeria should further enhance sound public financial management system in the Ministry of Communications and Digital Economy in order to improve ICT infrastructural development and ensure the control and monitoring of public resources meant for ICT infrastructural development by using public financial management system tools.

\section{References}

i. Adekalu, B. (2016). Infrastructure Development in Nigeria: Better Late than Never.Retrieved $28^{\text {th }}$ May 2020 from https://www.lexology.com>Infrastructure-Development-in-Nigeria-Better-Late-than-Never.

ii. Andersen, G. \&Isaken, V. (2013). Local Service Provision in Selected OECD Countries: Do Decentralized Operations Work Better? IIMF Working Paper 08/67.

iii. Bahrini, R. \&Qaffas, A. A. (2019). Impact of information and communication technology on economic growth: Evidence from developing countries. Economies, 7(1): https://doi.org/10.3390/economies7010021.

iv. Bankole, F. \&Mimbi, L. (2017). ICT infrastructure and its impact on national development: A research direction for Africa. The African Journal of Information Systems, 9(2): 1-26.

v. Bankole, F. O., Osei-Bryson, K. M. \& Brown, I. (2011). Investigating the impact of ICT investments on human development. The Electronic Journal on Information Systems in Developing Countries, 48(8): 1-19.

vi. Bariu, T. N. (2020). Status of ICT infrastructure used in teaching and learning in secondary schools in Merucounty, Kenya. European Journal of Interactive Multimedia and Education, 1(1): e02002. https://doi.org/10.30935/ejimed/8283.

vii. Brady, W. \&Elkner, J. (2017). History of Information Technology. Retrieved 15th June 2020 from:

viii. https://openbookproject.net/courses/intro2ict/history/history.html

ix. Broback, W. \&Sjolander, P. (2002). Programme Support and Public Finance Management: A New Role for Bilateral Donors. Stockholm: CIDA.

x. Brown, T. (2020). The Importance of Information and Communication Technology (ICT).

xi. Retrieved $15^{\text {th }}$ June 2020 from: https://itchronicles.com/information-and-communication-technology/theimportance-of-information-and-communication-technology-ict/

xii. Capra, F. (1997). The Web of Life. New York: Doubleday-Anchor Book.

xiii. Gabreab, F. A. (2002). Diffusion in African mobile telecommunications markets (Working Paper 2863). Washington DC: World Bank.

xiv. Government of Canada (2017). Public Financial Management. Retrieved $16^{\text {th }}$ June 2020 from: https://www.international.gc.ca/world-monde/issues_development-enjeux_developpement/human_rightsdroits_homme/financial_management-finances_publiques.aspx?lang=eng

xv. HLFP (2017). Thematic Review of SDG-9: Build resilient infrastructure, promote inclusive and sustainable industrialization and foster innovation. Retrieved 28 revOD.pdf

xvi. Law Insider (2020). Definition of ICT Infrastructure. Retrieved 28 $8^{\text {th }}$ May 2020 from: https://www.lawinsider.com/dictionary/ict-infrastructure

Lawson, A. (2015). Public Financial Management. Retrieved 4th June 2020 from: https://www.PFM_RP.pdf

xvii. Lee, K. S. \&Anas, A. (1992). Impact of Infrastructure Deficiencies on Nigerian Manufacturing.1818 H Street: The World Bank Publication.

xviii. National University of Singapore (2008). History of ICT. Retrieved 17th June 2020 from: https://wiki.nus.edu.sg/display/cs1105groupreports/History+of+ICT

xix. Nedozi, F. O., Obasanmi, J. O. \&Ighata, J. A. (2017). Infrastructure development and economic growth in Nigeria: using simultaneous equation. Journal of Economic, 5(3): 325-332. 
xx. Ngwenyama, O., Andoh-Baidoo, F. \&Morawczynski O. (2006). Is there a relationship between ICT, health, education and development? An empirical analysis of five West African Countries from 1997-2003. Electronic Journal of Information Systems and Developing Countries, 23(5): 1-11.

xxi. Nwezeaku, N. C. (2010). The impact of public sector financial management on the economies of Sub-Saharan Africa. International Research Journal of Finance and Economics, 40:

xxii. Ogujiuba, K. K. \&Ehigiamusoe, K. (2012). Capital budget implementation in Nigeria: Evidence from 2012 Capital budget. Contemporary Economics, 8(3): 299-314.

xxiii. Olokesusi, F. (2011). Planning and the Achievement of Nigeria Vision 20:2020. Paper submitted to the Presidential Committee of the Nigerian Institute of Town Planners on the State of Urban and Regional Planning in Nigeria. 1-9.

xxiv. Oloruntoyin, S. T. \&Adeyanju, I. A. (2013). The Role and Prospect of Information Communication Technology in National Development. International Journal of Computing Academic Research. (IJCAR), 2(3)

xxv. Pradhan, R. P., \&Bagchi, T. P. (2018). Information Communication Technology (ICT) infrastructure and economic growth: A causality evinced by cross-country panel data. IIMB Management Review, 33(1): 91-103.

xxvi. Prakash, T. \&Cabezon, E. R. (2008). Public Financial Management and Fiscal Outcomes in Sub-Saharan African Heavily-Indebted Poor Countries. Retrieved29th May 2020 from: https://papers.ssrn.com/so13/papers.cfm?abstract_id=1278428

xxvii. Schein, E. H. (1980). Organizational Psychology, 3rd edition. New Jersey: Prentice Hall.

xxviii. SIGMA-OECD (2014). Public Financial Management, Public Procurement and External Audit. Retrieved 30th May 2020 from: https://www.oecd.org/site/sigma/

xxix. Simson, R., Sharma, N. \& Aziz, I. (2011). A guide to Public Financial Management Literature. Retrieved from: https://www.odi.org/publications/6242-public-financial-management-pfm-guide

xxx. Siporin, M. (1975). Introduction to Social Work Practice. New York: Macmillan.

xxxi. Sirmon, D, G, Hitt, M. A. \& Ireland, R. D. (2007)). Managing firm resources in dynamic environments to create value: looking inside the black box. Academy of Management Review, 32(1): 273-292.

xxxii. TechTerms (2020).ICT Definition. Retrieved 15 th June 2020 from: https://techterms.com/definition/ict

xxxiii. The World Bank. (2018). Nigeria Public Sector Reform and Development Project. Retrieved 1 st June 2020 from Nigeria-PSGRDP-07312018.pdf

xxxiv. Tolica, E. K., Sevrani, K. \&Gorica, K. (2015). ICT Sector and the Importance of ICT Infrastructure. Management. Switzerland: Springer, Cham.

xxxv. World Bank Development Report. (1994). Infrastructure for Development - Executive Summary. Retrieved 16 ${ }^{\text {th }}$ June 2020 from: http://documents.worldbank.org/curated/en/687361468340136928/World-DevelopmentReport-1994-infrastructure-for-development-executive-summary. 